\title{
Perbandingan Tegangan Residu Arester SiC dan ZnO Terhadap Variasi Front Time
}

\author{
R.D. Puriyanto ${ }^{1}$, T. Haryono ${ }^{2}$, Avrin Nur Widiastuti ${ }^{3}$ \\ Universitas Ahmad Dahlan1, Universitas Gadjah Mada ${ }^{2,3}$ \\ e-mail : riky.dp@ee.uad.ac.id1
}

\begin{abstract}
Abtract
The high intensity of the occurrence of lightning causing lightning strike on many distribution lines. The characteristic of surge (over voltage) generated by lightning strike may change due to the impedance of distribution line. Arrester installation is expected to protect transformer as the main of the electrical system against the surge wave. There are two kinds of arrester according to the material, metal oxide ( $\mathrm{ZnO}$ ) and silicon carbide (SiC). Arrester $\mathrm{ZnO}$ replaces arrester SiC because it is considered better in providing protection against power equipment. this research was conducted on test scale laboratory to know the comparison of residual voltage as $\mathrm{ZnO}$ and $\mathrm{SiC}$ arrester output against surge wave that has variation of the front time value. The result shows that $\mathrm{ZnO}$ arrester thus has protection characteristic better than SiC arrester against surge with the variation of front time.
\end{abstract}

Keywords: front time; arrester; silicon carbide; zinc oxide; lightning; over voltage

\begin{abstract}
Abstrak
Tingginya intensitas terjadinya petir menyebabkan sambaran petir pada saluran daya listrik, khususnya saluran distribusi yang jumlahnya sangat banyak. Karakteristik gelombang surja (tegangan lebih) yang dihasilkan oleh sambaran petir dapat berubah akibat impedans saluran distribusi. Pemasangan arester diharapkan dapat melindungi transformator sebagai peralatan utama sistem kelistrikan terhadap gelombang surja. Terdapat dua macam arester berdasarkan bahannya, silicon carbide $(\mathrm{SiC})$ dan zinc oxide ( $\mathrm{ZnO}$ ). Arester dengan bahan $\mathrm{ZnO}$ banyak menggantikan arester dengan bahan $\mathrm{SiC}$ karena dianggap lebih baik dalam memberikan perlindungan terhadap peralatan daya. Pada penelitian ini dilakukan pengujian skala laboratrium untuk mengetahui perbandingan tegangan residu sebagai output arester $\mathrm{SiC}$ dan $\mathrm{ZnO}$ dalam menghadapi gelombang surja yang memiliki nilai waktu muka (front time) yang bervariasi. Hasilnya menunjukkan bahwa arester $\mathrm{ZnO}$ memang memiliki karakteristik perlindungan yang lebih baik dibanding arester $\mathrm{SiC}$ dalam menghadapi gelombang surja dengan front time yang bervariasi.
\end{abstract}

Kata Kunci: waktu muka; arester; silicon carbide; zinc oxide; petir, tegangan lebih

\section{Pendahuluan}

Indonesia merupakan negara beriklim tropis dengan curah hujan yang cukup tinggi. Secara tidak langsung kondisi tersebut berdampak pada tingginya Jumlah Hari Guruh (Thunder Storm Days) di Indonesia. Indonesia memiliki 200 hari guruh, jika dibandingkan dengan USA 100 hari, Brasil 40 hari dan Afrika 60 hari [1]. Ini menunjukkan bahwa Indonesia memiliki kerawanan yang cukup tinggi akibat bahaya sambaran petir. Hal ini didukung oleh nilai kerapatan petir di Indonesia yang mencapai 10 sambaran/km2/tahun [2]. Sambaran petir secara langsung maupun tidak langsung pada saluran tenaga listrik menghasilkan tegangan lebih (surja) yang mampu membahayakan peralatan di pusat pembangkitan atau gardu. Petir juga menjadi penyebab mayoritas kegagalan yang terjadi pada sistem daya listrik.

Bentuk gelombang sambaran petir, baik langsung maupun tidak langsung terhadap sistem daya listrik sangat sulit diprediksi. Salah satu parameter gelombang surja adalah waktu muka (front time) yang berbeda-beda pada setiap gelombang. Perubahan ini selain karena karakteristik asli gelombang petir, dapat dipengaruhi oleh adanya impedans saluran yang dilewati. Semakin panjang saluran akan mengakibatkan perubahan karakteristik gelombang yang dihasilkan, salah

Perbandingan Tegangan Residu Arester SiC dan ZnO Terhadap Variasi Front Time (R.D. Puriyanto) 
satunya adalah front time [3]. Nilai puncak surja petir adalah $45 \mu$ s yang merupakan representasi dari surja hubung (switching surge) dan surja sementara (temporary surge).

Berbagai standar menyatakan nilai waktu muka (front time) dan waktu ekor (tail time) yang berbeda-beda. Standar impuls petir yang biasa digunakan sesuai dengan standar IEC (International Electrotechnical Comission), IEEE (Institute of Electrical and Electronics Engineers), dan JIS (Japan Industrial Standards) adalah 1.2/50 $\mu \mathrm{s}$, untuk Jerman dan Inggris standar impuls adalah $1 / 50 \mu \mathrm{s}$, sedangkan Amerika Serikat menggunakan standar impuls 1.5/40 $\mu \mathrm{s}$. Perbedaan nilai front time pada beberapa standar tersebut menjadi latar belakang penelitian ini. Peralatan pelindung gelombang impuls harus mampu bekerja dengan baik untuk menanggulangi gangguan gelombang impuls petir yang memiliki variasi front time.

Gelombang yang dihasilkan dari sambaran petir merupakan salah satu dari penyebab gelombang berjalan (travelling wave). Adanya surja petir pada kawat saluran udara akan menimbulkan energi yang mengalir pada kawat tersebut secara tiba-tiba. Energi yang merambat melalui kawat terdiri dari arus dan tegangan yang nilainya besar. Kecepatan rambatan gelombang ini tergantung dari konstanta kawat penghantar. Pada kawat saluran udara kecepatan merambat mampu mencapai $360.000 \mathrm{~m} /$ detik [4].

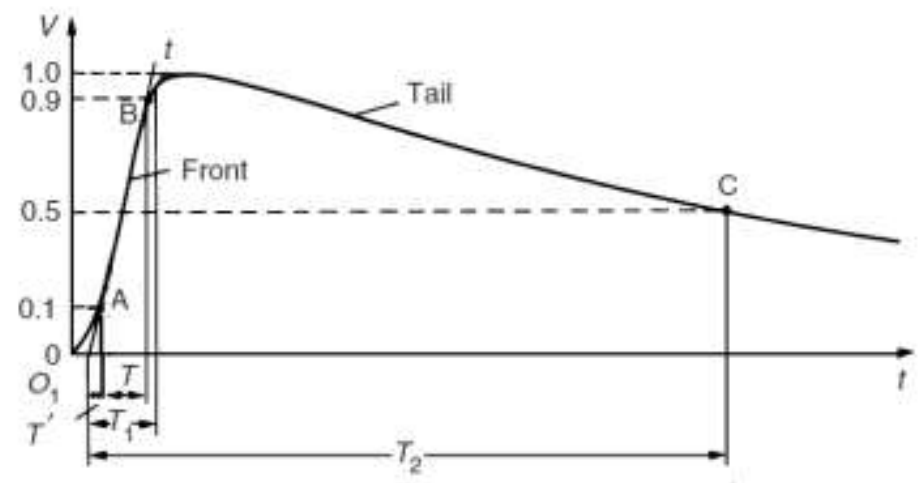

Gambar 1. Gelombang impuls penuh dengan $t_{1} 10 \%$

Gelombang berjalan yang terjadi akibat surja petir berbentuk gelombang impuls. Tegangan impuls seperti yang ditunjukkan pada Gambar 1 merupakan tegangan satu arah yang tanpa adanya osilasi yang cukup berarti, naik menuju nilai maksimum dengan cepat, dan turun menuju nilai nol lebih cepat atau dapat juga lebih lambat [5]. Nilai maksimum berada di puncak tegangan impuls tersebut. Jika tegangan impuls mengalami osilasi, nilai toleransi yang diperbolehkan menurut adalah $5 \%$ dari nilai puncak tegangan impuls.

Jika tegangan impuls yang muncul tidak menimbulkan flash over, maka disebut tegangan impuls penuh, namun jika flash over terjadi dan menyebabkan hilangnya tegangan impuls secara tiba-tiba, maka disebut tegangan impuls terpotong (chopped impulse voltage). Pada impuls tegangan penuh terdapat dua interval waktu, yaitu muka gelombang (wave front) dan ekor gelombang (wave tail).

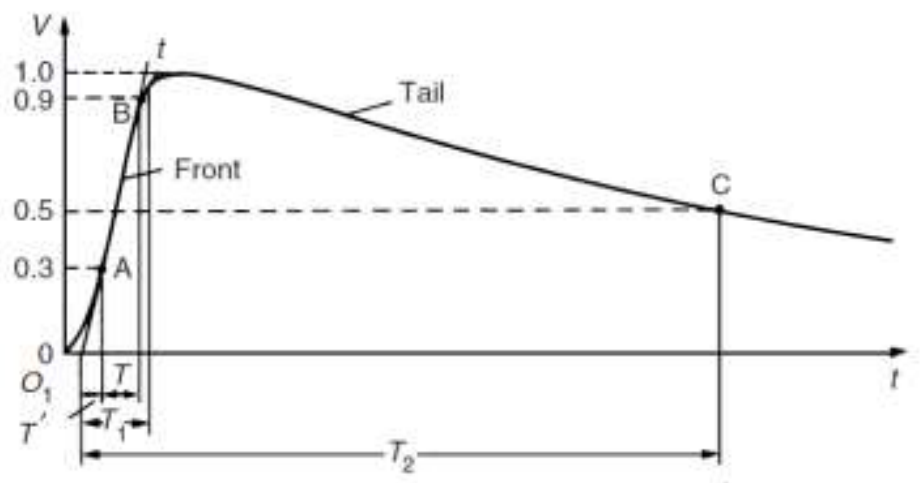

Gambar 2. Gelombang impuls penuh dengan $\mathrm{t}_{1} 30 \%$ 
Sesuai Gambar 1 di atas, waktu muka (front time) gelombang impuls didapatkan saat gelombang mencapai nilai puncak atau nilai maksimum dari nilai awal nol. Untuk mendapatkan nilai awal dan nilai puncak biasanya sulit, namun demikian, referensi [5] menyebutkan bahwa front time dapat didapatkan dari 1.25 kali $\left(\mathrm{t}_{2}-\mathrm{t}_{1}\right)$, dengan $\mathrm{t}_{2}$ adalah waktu gelombang mencapai $90 \%$ dari nilai puncak dan $\mathrm{t}_{1}$ adalah saat mencapai $10 \%$ dari nilai puncak. Dengan jarak $10 \%$ sampai $90 \%$ adalah $80 \%$, maka untuk mencapai nilai penuh, digunakan faktor pengali sebesar 1.25. Namun demikian, tidak semua sumber menggunakan faktor pengali yang sama. Referensi [6] menggunakan faktor pengali 1.67 untuk mendapatkan nilai front time. Hal ini disebabkan oleh perbedaan nilai $t_{1}$ yang didefinisikan, yaitu $30 \%$ dari nilai puncak tegangan. Hal ini dapat dilihat pada Gambar 2 di bawah. Dengan jarak 30\% sampai $90 \%$ adalah $60 \%$, maka faktor pengali untuk mendapatkan nilai front time menjadi 1.67 .

Nilai waktu ekor gelombang untuk gelombang impuls adalah sebesar (t3-to) yang diekspresikan pada Gambar 1 dan Gambar 2. Nilai tersebut didapatkan pada saat gelombang turun dan mencapai nilai $50 \%$ dari nilai puncak gelombang. Sesuai standard IEEE, front time dan tail time tegangan impuls petir adalah 1.2 dan $50 \mu \mathrm{s}$. Pada tegangan impuls nilai tersebut dieksprsikan menjadi 1.2/50 $\mu$ s sesuai kesepakatan yang berlaku.

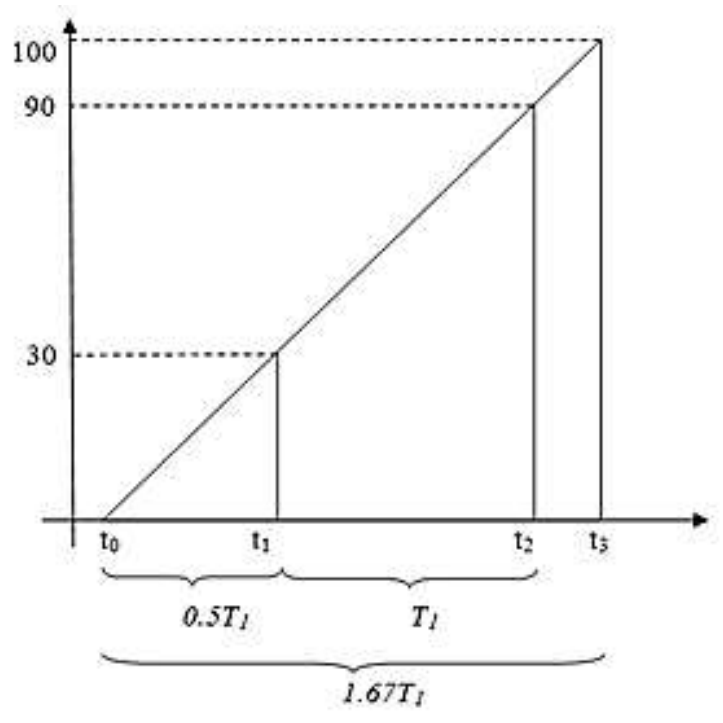

Gambar 3. Prinsip kesebangunan untuk menentukan nilai front time $\left(\mathrm{t}_{3}\right)$

Dengan melihat Gambar 3, kita dapat menghitung besarnya nilai $t_{3}$ dengan perbandingan segitiga yang ada. Berdasarkan pada Gambar 3, nilai front time $t_{3}$ didapat dari:

$t_{0}=t_{1}-0.5 T_{1}$

$t_{0}=t_{1}-0.5\left(t_{2}-t_{1}\right)$

Dengan diketahui nilai to, maka:

$t_{3}-t_{0}=1.67 T_{1}$

$t_{3}-t_{0}=1.67\left(t_{2}-t_{1}\right)$

$t_{3}=1.67\left(t_{2}-t_{1}\right)+t_{0}$

Alat pelindung yang digunakan pada peralatan listrik terhadap tegangan/arus impuls akibat petir adalah arester. Arester merupakan alat yang berfungsi untuk memotong tegangan lebih yang merambat di jaringan. Terdapat dua jenis blok arester yang memiliki karakteristik berbeda yang dibedakan berdasarkan jenis varistor yang digunakan, yaitu blok metal oxide $(\mathrm{ZnO})$ dan silicon carbide ( $\mathrm{SiC}$ ). Pada keadaan tegangan jaringan normal, arester berperan sebagai isolator. Tetapi ketika terjadi surja petir pada terminal arester maka arester akan berubah menjadi penghantar dan mengalirkan muatan surja petir tersebut ke tanah.

Karakteristik V-I bahan varistor dapat membuat arester memiliki karakteristik khusus untuk melewatkan tegangan/arus lebih pada kondisi tegangan normal, serta memiliki nilai hambatan yang sangat kecil pada saat terjadi gangguan petir. Tegangan residu (residual voltage) arester 
merupakan hasil pemotongan surja tegangan yang sampai ke arester pada saat surja tegangan tersebut memenuhi nilai tegangan yang mampu mengaktifkan arester. Besarnya batas nilai tegangan untuk membuat arester aktif tergantung pada rating arester itu sendiri.

Transformator merupakan peralatan yang sangat penting dalam proses pembangkitan tenaga listrik. Transformator perlu dilindungi dari gangguan surja petir karena selain memiliki peranan yang sangat penting, untuk mendapatkan transformator dengan pembangkitan optimal dan memiliki tahanan yang tinggi memerlukan biaya yang sangat mahal. Transformator memiliki parameter BIL (Basic Impulse Insulation Level) yang menjelaskan kemampuan transformator sendiri untuk bartahan dari tegangan impuls. Pada transformator $18 \mathrm{kV}$ nilai BIL ditetapkan sebesar $95 \mathrm{kV}$ pada karakteristik bentuk gelombang 1.2/50 $\mu \mathrm{s}$.

Tujuan utama dari perlindungan transformator dalam sistem daya listrik adalah untuk memenuhi kebutuhan konsumen akan daya listrik. Pengaruh perubahan front time akan didapatkan dari hasil pengujian skala laboratorium yang akan dilaksanakan pada penelitian ini. Kedua bahan arester, $\mathrm{ZnO}$ dan $\mathrm{SiC}$, akan diuji untuk mengetahui karakteristik perlindungan terhadap adanya tegangan impuls yang memiliki front time yang bervariasi. Hasil yang didapatkan akan digunakan sebagai sumber informasi berkaitan dengan kualitas perlindungan yang dihasilkan masing-masing arester.

\section{Metode Penelitian}

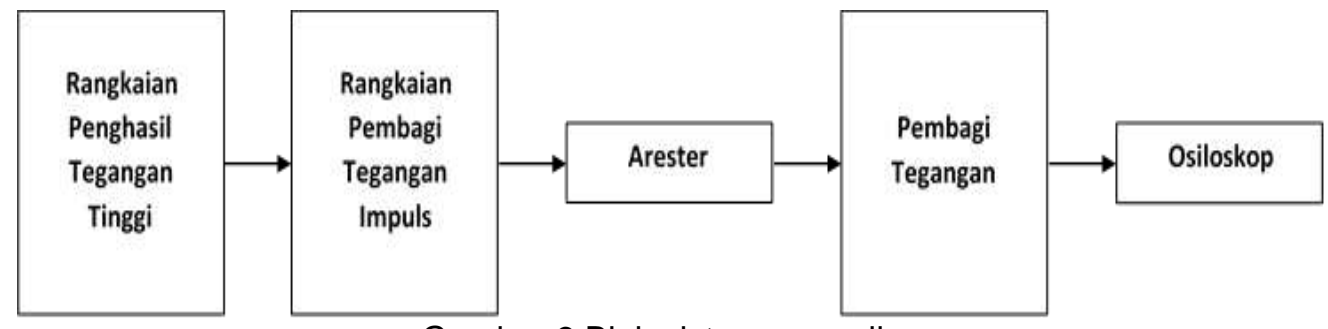

Gambar 3 Blok sistem pengujian

Penelitian tentang pengaruh front time terhadap tegangan residu arester $\mathrm{ZnO}$ dan $\mathrm{SiC}$ akan dilakukan dengan metode pengujian skala laboratorium. Pengujian dilakukan dengan menggunakan peralatan pengujian tegangan tinggi yang terdiri dari beberapa rangkaian yang memiliki fungsi khusus. Secara keseluruhan sistem pengujian pada penelitian ini ditunjukkan pada Gambar 3. Masing-masing blok berisi rangkaian komponen elektronika yang memiliki fungsi tersendiri. Pada sub bab selanjutnya akan dijelaskan fungsi masing-masing blok tersebut dan bahan arester yang digunakan sebagai bahan pengujian pada penelitian ini.

Penelitian ini dilakukan pada skala laboratorium dengan memanfaatkan pembangkit gelombang untuk menghasilkan tegangan tinggi sebagai representasi gelombang petir. Dengan melakukan modifikasi pada rangkaian pembangkit gelombang didapatkan gelombang surja yang memiliki variasi nilai front time. Diagram alir pada Gambar 5 menunjukkan langkah-langkah yang dilakukan pada pengujian ini.

1) Pengujian dimulai dengan mempersiapkan induktor dengan nilai yang bervariasi ( $L 1$ sampai L8) untuk dapat menghasilkan keluaran rangkaian pembangkit tegangan impuls dengan front time yang bervariasi.

2) Sebelum melakukan pengujian, jarak sela bola pada rangkaian pembangkit tegangan impuls diatur agar dapat menghasilkan nilai tegangan keluaran yang diinginkan. Dengan jarak sela bola yang optimal kita mampu melakukan proses trigger atau pelepasan muatan kapasitor pada nilai tegangan yang diinginkan.

3) Pengujian diawali dengan memberikan tegangan masukan (Vi) pada rangkaian pembangkit tegangan impuls dengan cara memutar triac pada panel kendali dan mengamati nilai tegangan yang mengalir pada multimeter.

4) Tegangan keluaran (Vpi) yang diinginkan pada pengujian sebesar $\pm 60 \mathrm{kV}$ dan $\pm 100 \mathrm{kV}$. Apabila nilai puncak tegangan keluaran belum mencapai nilai tersebut, akan dilakukan 
Jurnal IImu Teknik Elektro Komputer dan Informatika (JITEKI)

Vol. 2, No. 2, Desember 2016

pengujian ulang dengan mengubah nilai tegangan masukan hingga mendapatkan nilai tegangan keluaran yang diinginkan.

5) Setelah mendapatkan nilai tegangan keluaran yang diinginkan, maka gelombang tegangan yang tampil pada osiloskop dan data tegangan masukan disimpan sebagai dasar pengujian selanjutnya.

6) Hasil pengujian sebelumnya digunakan untuk pengujian arester $\mathrm{SiC}$ dan arester $\mathrm{ZnO}$.

7) Gelombang tegangan residu ( $\mathrm{Vpr}$ ) arester $\mathrm{SiC}$ dan $\mathrm{ZnO}$ yang tampil di osiloskop disimpan untuk dilakukan analisis.

Pengujian akan diulangi sampai nilai induktor habis (L1 sampai L8).

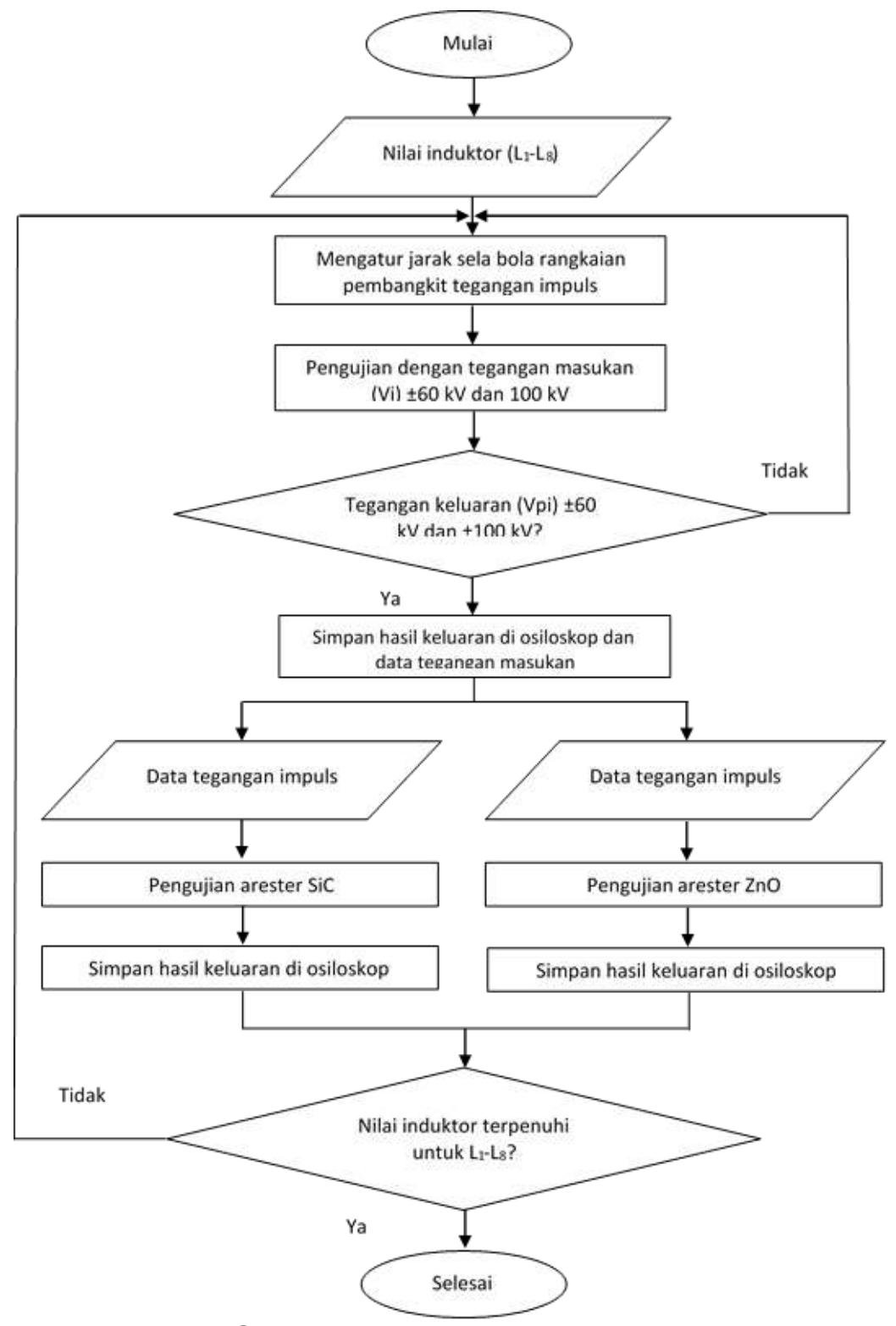

Gambar 5. Diagram alir pengujian

\section{Hasil dan Pembahasan}

\subsection{Perbandingan Tegangan Residu}

Arester $\mathrm{SiC}$ dan $\mathrm{ZnO}$ memiliki perbedaan dalam hal konstruksi. Perbedaan ini berpengaruh dalam pembentukan gelombang tegangan residu pada masing-masing arester. Pada arester SiC terdapat sela udara yang membuat tegangan residu arester SiC dihasilkan setelah terjadi gagal 
sela. Berbeda dengan arester $\mathrm{SiC}$, arester $\mathrm{ZnO}$ memiliki keunggulan dalam hal konstruksi dengan tidak memiliki sela udara sehingga surja langsung diterima oleh varistor $\mathrm{ZnO}$. Tegangan gagal sela yang dihasilkan arester SiC berkisar antara $42.71 \mathrm{kV}$ sampai $53.95 \mathrm{kV}$. Nilai rata-rata 8 pengujian yang dilakukan dengan $\mathrm{Vpi} 60 \mathrm{kV}$ adalah $50.09 \mathrm{kV}$. Nilai rata-rata tersebut hampir sama dengan nilai rata-rata pengujian dengan Vpi $100 \mathrm{kV}$, yaitu $50.16 \mathrm{kV}$. Dengan nilai tegangan gagal sela tersebut, arester $\mathrm{SiC}$ masih mampu menghasilkan perlindungan terhadap transformator 18 $\mathrm{kV}$ dengan BIL $95 \mathrm{kV}$.

Pada pengujian dengan tegangan $\mathrm{Vpi} 60 \mathrm{kV}$ kedua arester mampu menghasilkan tegangan residu di bawah nilai BIL. Nilai puncak tegangan residu rata-rata arester SiC pada pengujian dengan tegangan $\mathrm{Vpi} 60 \mathrm{kV}$ adalah $33.51 \mathrm{kV}$ dengan rentang antara $30.91 \mathrm{kV}-39.34$ $\mathrm{kV}$. Sedangkan pada arester $\mathrm{ZnO}$ puncak tegangan residu rata-rata yang dihasilkan sebesar $39.97 \mathrm{kV}$ dengan rentang antara $39.34 \mathrm{kV}-41.03 \mathrm{kV}$. Hasil tegangan residu arester SiC lebih rendah dibanding tegangan residu arester $\mathrm{ZnO}$. Namun rentang nilai tegangan residu arester $\mathrm{SiC}$ lebih besar dibanding tegangan residu arester $\mathrm{ZnO}$. Pada pengujian arester $\mathrm{SiC}$ maupun $\mathrm{ZnO}$ dengan tegangan $\mathrm{Vpi} 60 \mathrm{kV}$ menunjukkan kenaikan nilai front time cenderung menyebabkan penurunan tegangan residu arester $\mathrm{SiC}$ maupun $\mathrm{ZnO}$. Pada arester $\mathrm{SiC}$ penurunan terjadi sampai pengujian ke 8, namun pada arester $\mathrm{ZnO}$ tegangan residu hanya turun sampai pengujian 3 (waktu puncak $17 \mu \mathrm{s}$ ), setelahnya nilainya cenderung stabil. Walaupun demikian, tegangan residu arester $\mathrm{SiC}$ lebih rendah dibanding arester $\mathrm{ZnO}$.

Pada pengujian dengan tegangan Vpi $100 \mathrm{kV}$ kedua arester tetap mampu menghasilkan tegangan residu di bawah nilai BIL yang ditetapkan. Hasil nilai puncak tegangan residu arester $\mathrm{SiC}$ berkisar antara $37.09 \mathrm{kV}-43.91 \mathrm{kV}$ dengan rata-rata $39.91 \mathrm{kV}$. Sedangkan arester ZnO memiliki rentang nilai puncak tegangan residu antara $41.59 \mathrm{kV}-44.96 \mathrm{kV}$ dengan rata-rata 42.15 $\mathrm{kV}$. Dibandingkan dengan hasil sebelumnya dengan tegangan Vpi $60 \mathrm{kV}$, kenaikan tagangan Vpi mengakibatkan meningkatnya tegangan residu pada kedua jenis arester. Pada pengujian arester $\mathrm{SiC}$ maupun $\mathrm{ZnO}$ dengan tegangan $\mathrm{Vpi} 100 \mathrm{kV}$ menunjukkan kenaikan nilai front time cenderung menyebabkan penurunan tegangan residu arester SiC maupun $\mathrm{ZnO}$. Sama dengan pengujian dengan tegangan Vpi $60 \mathrm{kV}$, pada arester $\mathrm{SiC}$ penurunan terjadi sampai pengujian ke 8, namun pada arester $\mathrm{ZnO}$ tegangan residu hanya turun sampai pengujian 3 (waktu puncak $17 \mu \mathrm{s}$ ), setelahnya nilainya cenderung stabil.

Pada Gambar 6 terlihat bahwa nilai tegangan residu yang dihasilkan arester SiC lebih rendah dibanding tegangan residu arester $\mathrm{ZnO}$. Dari kedua pengujian yang dilakukan, dapat disimpulkan bahwa dengan kenaikan tegangan Vpi menyebabkan kenaikan tegangan residu pada arester $\mathrm{SiC}$ maupun $\mathrm{ZnO}$. Perubahan nilai front time menyebabkan penurunan nilai tegangan residu baik pada pengujian dengan tegangan Vpi $60 \mathrm{kV}$ maupun $100 \mathrm{kV}$. Pola penurunan tegangan residu pada kedua arester berbeda, pada arester $\mathrm{SiC}$ penurunan cenderung terjadi dari pengujian 1 sampai 8 , sedangkan pada arester $\mathrm{ZnO}$ penurunan tegangan residu cenderung terjadi pada pengujian 1 sampai 3 , setelahnya nilai tegangan residu cenderung stabil.

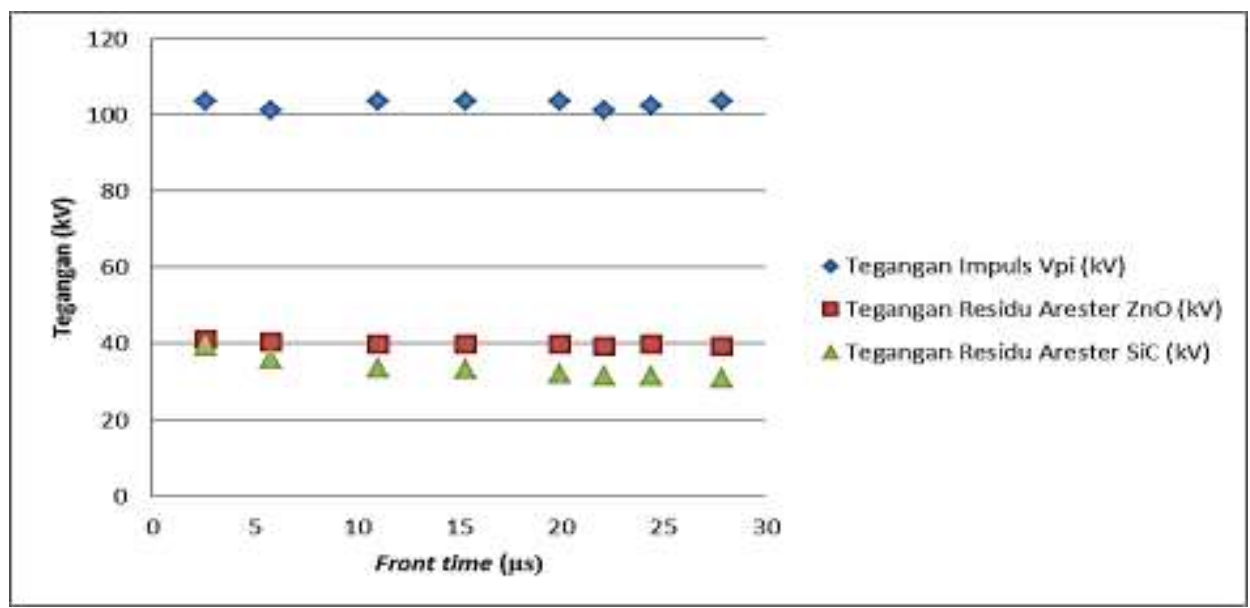

a. Dengan $\mathrm{Vpi}=60 \mathrm{kV}$ 
Jurnal IImu Teknik Elektro Komputer dan Informatika (JITEKI)

Vol. 2, No. 2, Desember 2016

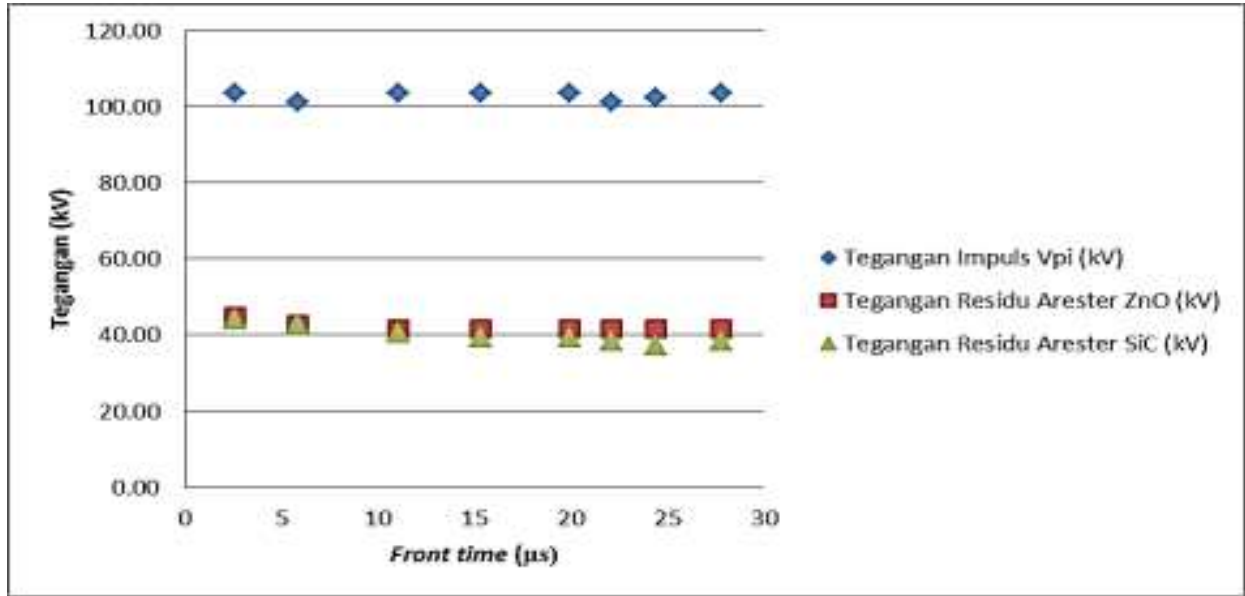

b. Dengan Vpi $=100 \mathrm{kV}$

Gambar 6. Perbandingan tegangan residu arester $\mathrm{SiC}$ dan $\mathrm{ZnO}$

\subsection{Perbandingan Bentuk Gelombang Tegangan Residu}

Berdasarkan bentuk gelombang yang terjadi, kedua arester menghasilkan tegangan residu yang lebih rendah dari nilai BIL. Pada Gambar 7 ditunjukkan bahwa tegangan residu yang dihasilkan oleh kedua arester memiliki perbedaan karakteristik. Arester $\mathrm{SiC}$ menghasilkan puncak tegangan gagal sela yang nilainya lebih tinggi dari tegangan residu yang dihasilkan. Nilai tegangan gagal sela ini menyebabkan puncak gelombang tegangan residu arester $\mathrm{SiC}$ lebih tinggi dari tegangan residu arester $\mathrm{ZnO}$. Namun demikian tegangan residu arester $\mathrm{SiC}$ nilainya lebih rendah dibanding tegangan residu arester $\mathrm{ZnO}$.

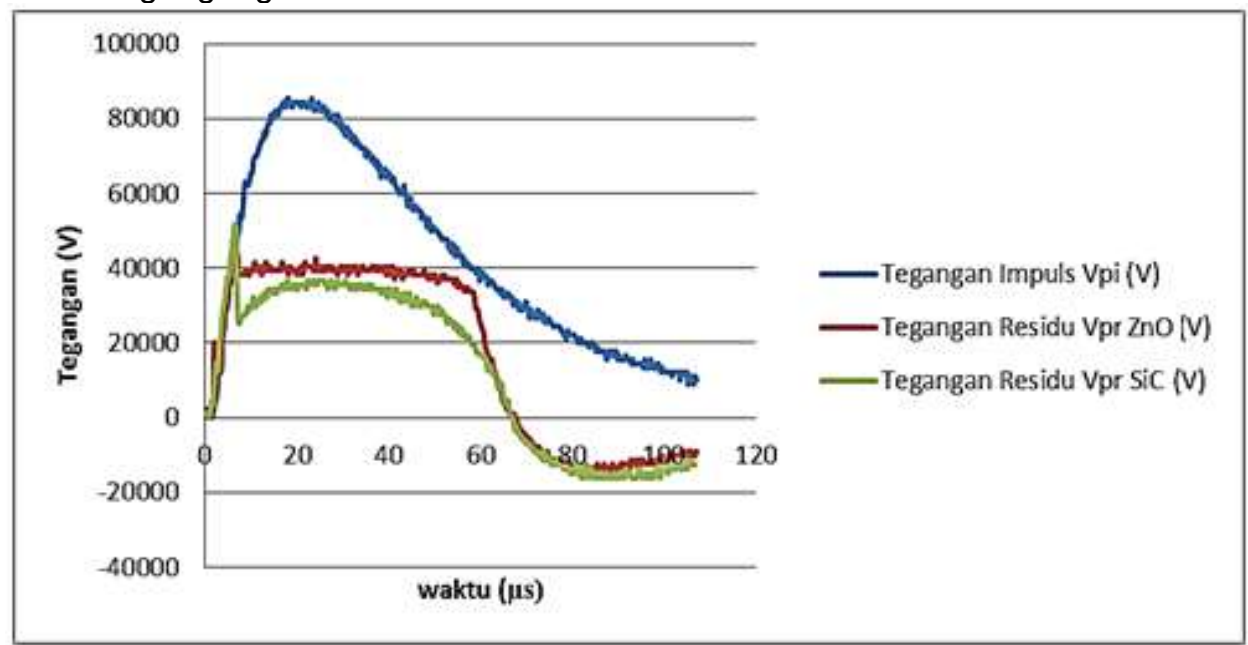

Gambar 7. Perbandingan bentuk tegangan residu arester SiC dan $\mathrm{ZnO}$

Waktu pemotongan tegangan surja arester $\mathrm{SiC}$ lebih lama dibandingkan arester $\mathrm{ZnO}$. Meningkatnya front time mengakibatkan durasi mencapai tegangan gagal sela juga semakin meningkat. Namun demikian, durasi mencapai puncak tegangan gagal sela yang meningkat ini tidak menyebabkan perubahan yang signifikan pada tegangan residu arester SiC. Berdasarkan Gambar 7 terlihat bahwa arester ZnO menghasilkan tegangan residu yang memiliki "punggung" yang lebih lebar dibanding arester SiC. "Punggung" pada arester $\mathrm{ZnO}$ memiliki puncak yang senilai dalam durasi tertentu, sedangkan pada arester SiC punggung yang dihaslkan mengikuti bentuk tegangan impuls. Lebar "punggung" gelombang tegangan residu arester $\mathrm{ZnO}$ dapat melebihi waktu discharge atau ekor gelombang tegangan impuls. Semakin tinggi front time, maka semakin panjang pula durasi "punggung" tegangan residu arester $\mathrm{ZnO}$ yang terjadi. Namun demikian, dalam kondisi gangguan petir dengan nilai front time kurang dari $30 \mu \mathrm{s}$ niilai puncak 
tegangan residu arester $\mathrm{SiC}$ maupun $\mathrm{ZnO}$ masih di bawah nilai BIL yang ditetapkan sehingga keduanya mampu memberikan perlindungan yang baik terhadap transformator $18 \mathrm{kV}$.

\section{Kesimpulan}

Kenaikan nilai front time cenderung menyebabkan penurunan tegangan residu arester $\mathrm{SiC}$ dan $\mathrm{ZnO}$. Secara keseluruhan nilai tegangan residu arester SiC lebih rendah dibanding tegangan residu arester $\mathrm{ZnO}$. Semakin besar nilai front time akan menghasilkan durasi "punggung" gelombang yang semakin panjang pada arester $\mathrm{SiC}$ dan $\mathrm{ZnO}$. Pada nilai front time yang besar durasi "punggung" tegangan residu arester $\mathrm{ZnO}$ dapat melebihi waktu discharge tegangan impuls (Vpi), namun hal ini tidak terjadi pada tegangan residu arester $\mathrm{SiC}$. Arester $\mathrm{ZnO}$ dinilai memiliki keunggulan dibanding arester SiC dengan menghasilkan tegangan residu murni tanpa adanya tegangan gagal sela seperti pada arester SiC. Namun arester SiC dan ZnO samasama memiliki keunggulan dalam menghadapi tegangan surja dengan front time yang bervariasi

\section{Referensi}

[1] Gunawan, T., Pandiangan, L. N. L., 2014. Analisis Tingkat Kerawanan Bahaya Sambaran Petir dengan Metode Simple Additive Weighting di Provinsi Bali

[2] Haryono, T., Sirait, K.T., 2011. Watak Perlindungan Blok ZnO yang Digunakan Pada Arester 20 KV Terhadap Sambaran Arus Impuls Berulang.

[3] Haddad, M., 2004. Advance in High Voltage Engineering (IEE Power and Energy). The Institution of Engineering Technology.

[4] Suyono, Haryono, T., Tumiran, 2000. Tanggapan Arester ZnO Terhadap Tegangan Surja dengan Berbagai Kecuraman Muka Gelombang.Tesis Jurusan Teknik Elektro.

[5] Wadhwa, C.L., 2010. High Voltage Engineering. New Age Science, Tunbridge Wells, UK.

[6] Kuffel, J., Kuffel, E., Zaengl, W.S., 2000. High Voltage Engineering Fundamentals. Newnes.

[7] Woodworth, J, 2008. Understanding Arrester Discharge Voltage 